\title{
Импульсно-периодический волоконный лазер для систем дальнометрии космических аппаратов
}

\author{
А.А. Колегов, А.В. Исаев ${ }^{*}$, Е.А. Белов, Е.Г. Акулинин, Ю.В. Осеев \\ Российский федеральный ядерньій иеентр - Всероссийский научно-исследовательский институт \\ технической физики имени академика Е.И. Забабахина \\ *E-mail:avisaev@bk.ru
}

DOI:10.31868/RFL2018.194

В настоящее время оптоволоконные лазеры широко применяются для решения различных задач науки и техники. На сегодняшний день наиболее востребованными областями применения импульсно-периодических иттербиевых волоконных лазеров являются обработка материалов, медицина, системы $3 \mathrm{~d}$ видения и дальнометрия. Особый интерес в использовании волоконных лазеров возник в космической технике. В первую очередь это связано с их компактностью, надежностью и высоким КПД “от розетки”. При минимально возможных габаритах такой лазер должен быть работоспособен при воздействии широкого диапазона температур окружающей среды, значительных механических нагрузок, факторов космического пространства.

Как правило, импульсно-периодические волоконные лазеры собираются по схеме «задающий генератор (ЗГ) - усилитель» (MOPA) [1,2]. В роли задающего генератора используется полупроводниковый лазерный диод. Излучение задающего генератора усиливается в многокаскадном волоконном усилителе. Оптическая схема лазера проработана с учётом возникновения возможных негативных эффектов (оптический пробой, ВКР).

Анализ результатов работ [3,4] и собственных исследований показал, что наиболее чувствительным компонентом оптоволоконного лазера с диодной накачкой к факторам космического пространства является активное волокно. Его облучение приводит к существенному росту неселективных потерь (уменьшение удельного пропускания излучения до 50\% при дозе облучения 100 кР [3]), воздействие радиационного излучения на глухую брэгговскую решётку приводит к уменьшению светопропускания на 30\% (при дозе облучения 100 кР). Элементы накачки не значительно меняют свои характеристики при облучении. Проведенные исследования [4] указывают, что наиболее радиационно-стойкими волокнами являются алюмосиликатные и фосфороалюмосиликатные световоды с избытком алюминия. Также показано, что накопленная доза облучения волокна снижается под воздействием оптического излучения и оптические характеристики волокна возвращаются к исходным.

В ходе теоретических и экспериментальных исследований проработана конструкция лазера, проведен тепловой анализ конструкции и теплонагруженных элементов.

В результате создан компактный (масса 2,5 кг), сохраняющий работоспособность в широком диапазоне температур иттербиевый импульснопериодический волоконный лазер с длительностью импульса 3 нс, частотой следования импульсов 11 кГц и энергией в импульсе 180 мкДж.

\section{Литература}

[1] V. Khitrov, B. Samson, Proc. of SPIE Vol. 6873 (2008)

[2] Bertand Morasse, Stephane Chatigny, Proc. of SPIE Vol,17539-17544 (2012).

[3] S. Girard, Y. Ouerdane, et al, IEEE transactions on nuclear science 56 (6), 3293, (2009)

[4] К.В. Зотов, ИОФ РАН (2010) 